\title{
Sea surface temperature and salinity variability at Bermuda during the end of the Little Ice Age
}

\author{
Nathalie F. Goodkin, ${ }^{1,2}$ Konrad A. Hughen, ${ }^{3}$ William B. Curry, ${ }^{4}$ Scott C. Doney, ${ }^{3}$ \\ and Dorinda R. Ostermann ${ }^{4}$
}

Received 9 August 2007; revised 31 October 2007; accepted 13 March 2008; published 9 July 2008

[1] We use geochemical and isotope measurements on a 225-year old brain coral (Diploria labyrinthiformis) from the south shore of Bermuda $\left(64^{\circ} \mathrm{W}, 32^{\circ} \mathrm{N}\right)$ to construct a record of decadal-to-centennial-scale climate variability. The coral was collected alive, and annual density bands visible in $\mathrm{X}$ radiographs delineate cold and warm seasons allowing for precise dating. Coral skeletons incorporate strontium $(\mathrm{Sr})$ and calcium $(\mathrm{Ca})$ in relative proportions inversely to the sea surface temperature (SST) in which the skeleton is secreted. Previous studies on this and other coral colonies from this region document the ability to reconstruct mean annual and wintertime SST using Sr/Ca measurements (Goodkin et al., 2007, 2005). The coral-based records of SST for the past 2 centuries show abrupt shifts at both decadal and centennial timescales and suggest that SST at the end of the Little Ice Age (between 1840 and 1860) was $1.5^{\circ} \pm 0.4^{\circ} \mathrm{C}$ colder than today (1990s). Coral-reconstructed SST has a greater magnitude change than does a gridded instrumental SST record from this region. This may result from several physical processes including high rates of mesoscale eddy propagation in this region. Oxygen isotope values $\left(\delta^{18} \mathrm{O}\right)$ of the coral skeleton reflect changes in both temperature and the $\delta^{18} \mathrm{O}$ of seawater $\left(\delta \mathrm{O}_{\mathrm{w}}\right)$, where $\delta \mathrm{O}_{\mathrm{w}}$ is proportional to sea surface salinity (SSS). We show in this study that mean annual and wintertime $\delta^{18} \mathrm{O}$ of the carbonate $\left(\delta \mathrm{O}_{\mathrm{c}}\right)$ are correlated to both SST and SSS, but a robust, quantitative measure of SSS is not found with present calibration data. In combination, however, the $\mathrm{Sr} / \mathrm{Ca}$ and $\delta \mathrm{O}_{\mathrm{c}}$ qualitatively reconstruct lower salinities at the end of the Little Ice Age relative to modern day. Temperature changes agree with other records from the Bermuda region. Radiative and atmospheric forcing may explain some of the SST variability, but the scales of implied changes in SST and SSS indicate large-scale ocean circulation impacts as well.

Citation: Goodkin, N. F., K. A. Hughen, W. B. Curry, S. C. Doney, and D. R. Ostermann (2008), Sea surface temperature and salinity variability at Bermuda during the end of the Little Ice Age, Paleoceanography, 23, PA3203, doi:10.1029/2007PA001532.

\section{Introduction}

\subsection{Little Ice Age}

[2] The Little Ice Age (LIA) was a series of extended cold periods that occurred from the mid-1400s to the late $1800 \mathrm{~s}$, documented primarily in the Northern Hemisphere [Bradley and Jones, 1993; Jones et al., 1998; Overpeck et al., 1997]. High-resolution paleoclimate records of the LIA exist from tree rings [Briffa et al., 2001; Esper et al., 2002; Jacoby and D’Arrigo, 1989], ice cores [Dahl-Jensen et al., 1998; Dansgaard et al., 1975], and coral records from the Caribbean Sea [Druffel, 1982; Watanabe et al., 2001; Winter et al., 2000]. These and other proxy reconstructions from around the North Atlantic show that land and ocean surface temperatures during the LIA were $0.5^{\circ}$ to $5^{\circ} \mathrm{C}$ lower than today, depending on location [deMenocal et al., 2000;

\footnotetext{
${ }^{1}$ MIT/WHOI Joint Program, Woods Hole, Massachusetts, USA.

${ }^{2}$ Now at Bermuda Institute of Ocean Sciences, St. Georges, Bermuda.

${ }^{3}$ Department of Marine Chemistry and Geochemistry, Woods Hole Oceanographic Institution, Woods Hole, Massachusetts, USA.

${ }^{4}$ Department of Marine Geology and Geophysics, Woods Hole Oceanographic Institution, Woods Hole, Massachusetts, USA.

Copyright 2008 by the American Geophysical Union. 0883-8305/08/2007PA001532\$12.00
}

Druffel, 1982; Dunbar et al., 1994; Glynn et al., 1983; Keigwin, 1996].

[3] The LIA is the most recent example of regional decadal-to-centennial-scale climate change events observed during the late Holocene [e.g., Bond et al., 1997; DahlJensen et al., 1998]. These events are of interest, in part, because improving our understanding of the mechanisms and patterns of such natural climate change will improve our ability to anticipate and evaluate future changes on similar timescales. Several forcing mechanisms have been put forth as possible causes for the Little Ice Age, including solar activity, which was low during this time [Crowley, 2000; Lean et al., 1995; Wigley and Kelly, 1990], and volcanic activity, which was observed to have been high [Crowley, 2000]. Both solar and volcanic influences have the potential to produce widespread cooling across the globe.

\subsection{Coral-Based Proxy Records}

[4] Coral skeletons provide high-resolution, long records of climatic and oceanographic variability. The strontium $(\mathrm{Sr})$ to calcium $(\mathrm{Ca})$ ratio of coral skeleton is inversely related to the sea surface temperature (SST) in which the coral grew [Smith et al., 1979] and provides a salinityindependent record of local SSTs [Beck et al., 1992, 1997]. Skeletal $\delta^{18} \mathrm{O}\left(\delta \mathrm{O}_{\mathrm{c}}\right)$ is governed by both SST and the $\delta^{18} \mathrm{O}$ 
of seawater $\left(\delta \mathrm{O}_{\mathrm{w}}\right)$, which is linearly related to sea surface salinity (SSS). Therefore, in combination, $\delta \mathrm{O}_{\mathrm{c}}$ and $\mathrm{Sr} / \mathrm{Ca}$ provide the means to estimate records of both SST and SSS $\left(\delta \mathrm{O}_{\mathrm{w}}\right)$ back through time [Gagan et al., 1998; Iijima et al., 2005; Quinn and Sampson, 2002; Watanabe et al., 2001].

[5] Here we use $\mathrm{Sr} / \mathrm{Ca}$ and $\delta^{18} \mathrm{O}$ from a slow growing coral from Bermuda to reconstruct SST and SSS, for a 218-year period (1781-1999). We evaluate interannual and wintertime SST and SSS $\left(\delta \mathrm{O}_{\mathrm{w}}\right)$ variations based upon monthly resolution records of $\mathrm{Sr} / \mathrm{Ca}$ and $\delta^{18} \mathrm{O}$ from a brain coral (Diploria labyrinthiformis). Growth rate, particularly in slow growing corals, has been shown to impact the relationship between coral $\mathrm{Sr} / \mathrm{Ca}$ and $\mathrm{SST}$ [Alibert and McCulloch, 1997; Cardinal et al., 2001; Cohen and Hart, 1997; Cohen et al., 2004; de Villiers et al., 1995, 1994; Goodkin et al., 2007, 2005]. Previous studies at Bermuda quantified the influence of both mean annual and lifetime, colony-average growth rates on mean annual $\mathrm{Sr} / \mathrm{Ca}$ values generated by the methods used in this paper [Goodkin et al., 2007, 2005]. In contrast, winter (December-March) $\mathrm{Sr} / \mathrm{Ca}$ values show no correlation to growth rate [Goodkin et al., 2005]. Therefore, in this study, we use a previously developed mean annual calibration of coral Sr/Ca to SST including coral growth rate effects, and a newly developed, nongrowth-dependent wintertime $\mathrm{Sr} / \mathrm{Ca}-\mathrm{SST}$ calibration. Mean annual and winter SSTs are then reconstructed, and compared to $\delta^{18} \mathrm{O}_{\mathrm{c}}$ to evaluate directional changes in salinity.

\section{Methods}

\subsection{Study Site}

[6] In 2000, a 225-year old brain coral colony (BB 001) was collected live from the southeastern edge of the Bermuda platform at $16 \mathrm{~m}$ water depth. Two smaller corals (BER 002 and BER 003) were collected from the same location to examine reproducibility between coral colonies and are used in this work to evaluate winter $\mathrm{Sr} / \mathrm{Ca}$, as previously done for mean annual $\mathrm{Sr} / \mathrm{Ca}$ [Goodkin et al., 2007]. Bermuda is one of the northernmost locations for surface coral growth and is near a deep sea sediment drift deposit with high accumulation rates. Bermuda has been the location for several proxy reconstructions of past climate from corals [Draschba et al., 2000; Druffel, 1997; Kuhnert et al., 2005], planktonic foraminifera [Keigwin, 1996] and alkenones [Ohkouchi et al., 2002; Sachs and Lehman, 1999].

[7] The island of Bermuda $\left(64^{\circ} \mathrm{W}, 32^{\circ} \mathrm{N}\right)$ is located in the Sargasso Sea in the subtropical North Atlantic. This site is oceanographically important because a large portion of the world's ocean heat transport from low to high latitudes occurs in the North Atlantic via the Gulf Stream. In addition, Sargasso Seawater interacts with both warmer tropical and cooler subarctic water [Curry et al., 2003; Talley, 1996]. Oceanographic conditions at Bermuda include a deep mixed layer in the winter $(>150 \mathrm{~m})$ and a shallow mixed layer in the summer $(\sim 10 \mathrm{~m})$. The south shore, from where the coral was collected, can however, experience upwelling in the summer when winds originate from the southwest. Finally, sea surface temperatures throughout the region are impacted by mesoscale eddy activity, propagated from the Gulf Stream, which generate both warm and cool temperature anomalies [Doney, 1996; Sweeney et al., 2003]. The coral reef sampled is from the outermost edge of the Bermuda reefs and exists at depth of $\sim 15 \mathrm{~m}$. Therefore, the reef is not subject to breaking waves and intensive mixing.

[8] The southern platform of Bermuda is in close proximity to Hydrostation $\mathrm{S}$, which lies $30 \mathrm{~km}$ to the southeast $\left(32^{\circ} 10^{\prime} \mathrm{N}, 64^{\circ} 30^{\prime} \mathrm{W}\right)$. Since 1954 , Hydrostation $\mathrm{S}$ has been visited approximately biweekly, and ongoing research includes the measurement of SST and SSS. Coral geochemical data from multiple coral colonies collected off southern Bermuda (including the multicentury coral used in this study) have previously shown correlations to Hydrostation $\mathrm{S}$ temperature for the calibration period of 1976 to 1997 [Goodkin et al., 2007, 2005]. Monthly averaged SST, computed with all Hydrostation $\mathrm{S}$ data from the surface down to the coral collection depth of $16 \mathrm{~m}$, ranges from $18.0^{\circ}$ to $28.9^{\circ} \mathrm{C}$. Annually averaged SSTs vary from $22.4^{\circ}$ to $24.3^{\circ} \mathrm{C}$. Monthly SSS (also averaged from the surface to $16 \mathrm{~m}$ ) varies from 36.1 to $36.8 \mathrm{psu}$, and annually averaged SSS has a range of 36.3-36.6 psu. The Hydrostation S SST and SSS records are incomplete over several intervals, with 2 or more months of SST and/or SSS missing in 1954, 1956-1957, 1968, 1971-1972, 1974, 1978-1980, 1986, and 1989. In this paper, we also compare the coral records to observed regional SST records (HadISST) from the gridded area $31^{\circ}-33^{\circ} \mathrm{N}$ and $64^{\circ}-65^{\circ} \mathrm{W}$ over the period 1870 to 1997 [Rayner et al., 2003].

[9] The Hydrostation S data used here for calibrations were compiled by first averaging data by the calendar month in which the data were measured. Monthly means were then averaged to generate the mean annual and wintertime records, with years missing two or more months excluded. Alternatively, Hydrostation S data were also compiled by interpolating SST to 20 evenly sampled dates per year, which were then averaged into mean annual and wintertime records. Both methods return statistically equivalent (within $1 \sigma$ uncertainty) $\mathrm{Sr} / \mathrm{Ca}-\mathrm{SST}$ regressions. (Note that the two calibration equations, from the differently processed instrumental records applied to the mean annual $\mathrm{Sr} / \mathrm{Ca}$ data, result in an average reconstructed SST difference (root mean square of the residuals) of $0.6^{\circ} \mathrm{C}$, equivalent to the average error on the reconstruction reported here.)

\subsection{Subsampling}

[10] The coral slabs were cut, cleaned and x-rayed according to methods previously described [Goodkin et al., 2005]. Approximate monthly samples were drilled using a micrometer controlled drill press every $0.33 \mathrm{~mm}$ (BB 001) and $0.25 \mathrm{~mm}$ (BER 002, BER 003) along the dense thecal wall. The mass of individual samples averaged $220 \mu \mathrm{g}$. BB 001 samples were split into aliquots $(\sim 8-40 \mu \mathrm{g})$ for stable isotope analysis, with the remaining portion used for $\mathrm{Sr} / \mathrm{Ca}$ analysis. The thecal wall was chosen, despite complicated skeletal architecture [Cohen et al., 2004], because it is the densest skeletal component with the least potential impact from diagenesis. Two hundred and eighteen years were 
sampled, limited by our ability to capture the major growth axis in the oldest slab.

\section{3. $\mathrm{Sr} / \mathrm{Ca}$ Analysis}

[11] $\mathrm{Sr}$ and $\mathrm{Ca}$ were analyzed simultaneously using inductively coupled plasma-atomic emission spectrometry (ICP-AES) at the Woods Hole Oceanographic Institution (WHOI). Samples were dissolved in $1 \mathrm{~N}^{-} \mathrm{HNO}_{3}^{-}$to a concentration as close as possible to $80 \mathrm{ppm} \mathrm{Ca}$ based on mass, in order to minimize matrix corrections. Solution standards were employed to evaluate and correct for drift and matrix effects [Schrag, 1999]. An external powder standard of homogenized coral (Porites) was measured simultaneous to unknowns and blanks to evaluate precision. Repeat measurements on the external coral standard (run at variable concentrations matching the range of unknowns) analyzed over more than a year showed good reproducibility (standard deviation $(\mathrm{SD})=0.0244 \mathrm{mmol} / \mathrm{mol}$, residual $\mathrm{SD}$ (or coefficient of variation) $=0.27 \%, \mathrm{n}=1,493$ ). A small long-term drift (over several months) in the homogenous coral standard was observed on the order of 0.011 $\mathrm{mmol} / \mathrm{mol}$, and corrections were made to the unknowns as described by Goodkin [2007].

\subsection{Stable Oxygen Isotope Analysis}

[12] Stable oxygen isotopes were analyzed on a Finnigan MAT 253 isotope ratio mass spectrometer coupled to a Kiel III carbonate device at WHOI. Conversion to the Vienna Peedee belemnite (VPDB) scale was completed using comparison to an external standard, NBS19 $\left(\delta^{18} \mathrm{O}=\right.$ $-2.20 \%$ ). Reproducibility was $\pm 0.11 \%$ o $(\mathrm{n}=660)$ based on Estremoz marble (WHOI internal standard; $\delta^{18} \mathrm{O}=$ $-5.98 \%$ relative to VPDB), which has values closest to the coral unknowns. Corrections were required for small samples $(9 \%$ of total), generally resulting from the low sample mass required for approximately monthly sampling. Corrections for samples generating less than $0.8 \mathrm{~V}$ were minimal, with a maximum correction of $0.2 \%$ for samples generating $0.4 \mathrm{~V}$, the smallest voltage included in the data set. Corrections were also required for samples with poorly balanced sample-to-standard reference gas voltages $(11 \%$ of total). Such unbalanced samples resulted when samples $>$ $35 \mu \mathrm{g}$ were integrated into mass spectrometer runs with significantly smaller samples and from a jammed bellows pin preventing proper balancing over several days. These corrections were up to $0.2 \%$ for a sample/standard voltage of 2.5, the maximum correction. Details of these corrections are described by Goodkin [2007].

\subsection{Age Model Development}

[13] Age models were developed using density banding visible in the $\mathrm{X}$ radiographs to identify the calendar year. $\mathrm{X}$ radiographs for these corals have been previously published [Goodkin, 2007; Goodkin et al., 2007, 2005]. For the instrumental period, subannual age models were then generated by correlating $\mathrm{Sr} / \mathrm{Ca}$ to monthly averaged SSTs at maxima, minima and inflection points. Over the length of the entire long record (BB 001), three slabs were cut to capture changes in the primary growth axis through time. Multiple tracks were drilled within each slab, as well as across different slabs, to produce a continuous record along the growth axis. $\mathrm{X}$ radiographs and algal bands provided time horizons to overlap samples during transitions between slabs. Overlapping $\mathrm{Sr} / \mathrm{Ca}$ and $\delta^{18} \mathrm{O}$ measurements were averaged. The correlation coefficient for $\mathrm{Sr} / \mathrm{Ca}$ values between overlapping slabs shows strong agreement (average $\mathrm{r}=0.83$ ), as previously found [Goodkin et al., 2005].

[14] Beyond the instrumental record, months were assigned based on an average climatology of the Hydrostation S data, again matching $\mathrm{Sr} / \mathrm{Ca}$ and SST maxima, minima and inflection points within the seasonal cycle. The geochemical data were then interpolated to evenly spaced monthly increments. Before interpolation, the record had an average of 10.5 samples per year and a median of 11 samples per year. Annual (January-January) and wintertime (December-March) values were calculated from the interpolated monthly data.

[15] Some error is expected within this age model because of years of very little or no growth, not visible on the X ray and also not clearly discernible in the seasonal cycles of $\mathrm{Sr} /$ $\mathrm{Ca}$. While there is the potential for error generated by noise in the $\mathrm{Sr} / \mathrm{Ca}$ or the annual band counting to result in the inappropriate addition of a year, the majority of age model error will arise because of missing years, generating a bias in which coral bands are assigned to artificially recent (younger) dates. For example, if the coral did not grow in 1950,1949 would be inappropriately assigned the date 1950 , and similarly for all coral years prior to 1950 (1781-1949). Such age model bias is suspected during the early to mid-1800s when growth rates were extremely slow for an extended period of time and hiatuses in growth may have occurred [Goodkin et al., 2005].

\section{Results}

[16] The monthly coral $\mathrm{Sr} / \mathrm{Ca}$ and $\delta^{18} \mathrm{O}$ records show distinct seasonal cycles throughout the calibration period (Figure 1) and the entire length of the record. The calibration period of 1976-1997 is consistent with previous work [Goodkin et al., 2007, 2005] and allows for 22 years (1954-1975) of additional Hydrostation S data to evaluate the accuracy of reconstructed SST. Monthly $\mathrm{Sr} / \mathrm{Ca}$ and $\delta^{18} \mathrm{O}$ show a strong correlation from 1976 to $1997\left(\mathrm{r}^{2}=0.70\right)$, as they are both driven in large part by SST. An offset in the timing of $\delta^{18} \mathrm{O}$ and $\mathrm{Sr} / \mathrm{Ca}$ cycles is evident, with $\delta^{18} \mathrm{O}$ reaching maxima and minima on average one month later in time than $\mathrm{Sr} / \mathrm{Ca}$. This difference in timing likely results from the added influence of SSS on oxygen isotopic values, as a similar phase difference is seen between SST and SSS within the Hydrostation S record. In addition, mean annual correlations are insignificant $\left(\mathrm{r}^{2}<0.10\right)$, further supporting the conclusion that SST-SSS signals are both apparent in the oxygen isotope record.

\section{1. $\mathrm{Sr} / \mathrm{Ca}-\mathrm{SST}$}

\subsubsection{Mean Annual Reconstruction}

[17] Previous work has shown that mean annual $\mathrm{Sr} / \mathrm{Ca}$ $(\mathrm{mmol} / \mathrm{mol})$ in slow growing corals varies according to SST as well as mean annual and colony-average growth rates (mm/a) [Goodkin et al., 2007, 2005]. Several hypotheses have been presented for why growth rate may impact the mean annual $\mathrm{Sr} / \mathrm{Ca}-\mathrm{SST}$ calibration, including the influ- 


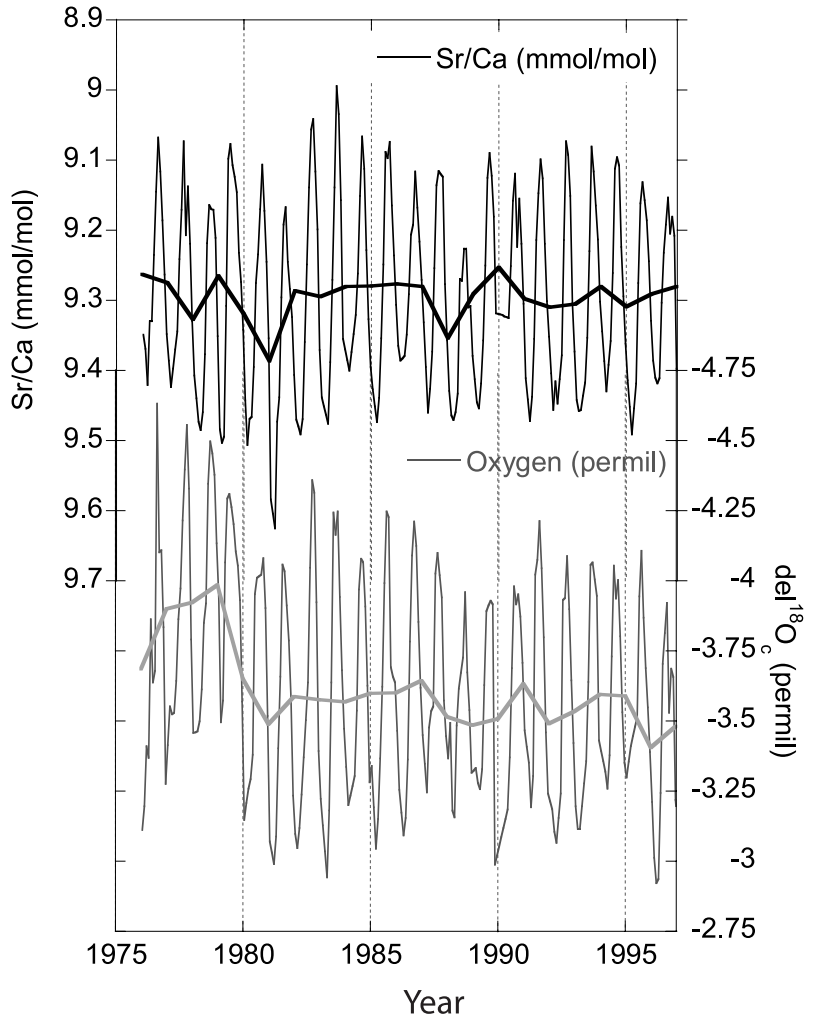

Figure 1. Monthly and mean annual $\mathrm{Sr} / \mathrm{Ca}(\mathrm{mmol} / \mathrm{mol})$ and $\delta^{18} \mathrm{O}(\%)$ records from a brain coral of the south shore of Bermuda plotted versus time from 1976 to 1997 . Both monthly geochemical proxies show an inverse relationship to $\operatorname{SST}\left(\mathrm{r}^{2}=0.86\right.$ and 0.69 , respectively). The $\delta^{18} \mathrm{O}$ is additionally correlated to SSS $\left(\mathrm{r}^{2}=0.32\right)$. For a detailed discussion of mean annual $\delta^{18} \mathrm{O}$, please see Text $\mathrm{S} 2$.

ence of bulk sampling [Cohen et al., 2004; Cohen and Thorrold, 2007; Swart et al., 2002], kinetic effects [de Villiers et al., 1994; Ferrier-Pages et al., 2002; Ip and Krishnaveni, 1991], and coral growth mechanisms including a dense summer layer generated from summer extension and winter infilling via calicification [Cohen et al., 2004]. For this work, mean annual SST $\left({ }^{\circ} \mathrm{C}\right)$ was calculated using a previously published, growth-corrected model based on multiple corals [Goodkin et al., 2007]:

$$
\begin{aligned}
& \mathrm{Sr} / \mathrm{Ca}=(-0.000697( \pm 0.000751) * i g \\
&+0.00304( \pm 0.00102) * a g-0.0738 .( \pm 0.0374)) \\
& * \mathrm{SST}+10.8( \pm 0.9) \\
&\left(2 \sigma, 95 \% \text { conf., } \mathrm{r}^{2}=0.51, \mathrm{~F}_{\mathrm{sig}} \ll 0.0001,\right. \\
&\left.\mathrm{rmsr}=0.5^{\circ} \mathrm{C}, \text { se }=0.031 \mathrm{mmol} / \mathrm{mol}\right)
\end{aligned}
$$

where ig is the interannual growth rate $(\mathrm{mm} / \mathrm{a})$ for each year and $a g$ is the average growth rate $(\mathrm{mm} / \mathrm{a})$ for the entire colony. RMSR is the root mean square of the residuals when the regression is inverted and used to calculate SST. SE is the standard error on $\mathrm{Sr} / \mathrm{Ca}$ predicted by the regression.
Covariance errors among the slopes and intercepts are reported in Table 1 . The average growth rate for BB 001 is $3.8 \mathrm{~mm} / \mathrm{a}$ as determined by $\mathrm{X}$ radiographs, and interannual growth rates are smoothed using a box window over 3 years according to Goodkin et al. [2005]. This calibration equation was generated using data from BB 001, BER 002, and BER 003 [Goodkin et al., 2007].

[18] We reconstruct mean annual SST from the 218-year $\mathrm{Sr} / \mathrm{Ca}$ record by inverting the regression (equation (1)) to find $\mathrm{SST}$ as a function of $\mathrm{Sr} / \mathrm{Ca}$ and growth rate (Figures $2 \mathrm{a}-$ 2c). Standard methods of error propagation [Bevington, 1969], including the slope and intercept errors shown with equation (1) and slope and intercept covariance values (Table 1), are used to estimate the error in the reconstructed SST, as detailed by Goodkin [2007]. Error for the $\mathrm{Sr} / \mathrm{Ca}$ data was based on the standard error of the regression $(0.031 \mathrm{mmol} / \mathrm{mol})$, which is somewhat larger than the measurement error $(0.0244 \mathrm{mmol} / \mathrm{mol})$, providing a more statistically conservative result. We have assumed no error in growth rate measurements. The $1 \sigma$ SST uncertainty for the mean annual calibration has an average value of $\pm 0.6^{\circ} \mathrm{C}$ $\left(\max =1.0^{\circ} \mathrm{C}\right.$ and $\left.\min =0.5^{\circ} \mathrm{C}\right)$ back to 1782 (Figure 2). The propagated error is larger during some periods of the record than that found for the calibration period because of variations in coral growth rate, which adds uncertainty to the reconstruction.

[19] Mean annual $\mathrm{Sr} / \mathrm{Ca}$ values range from $9.16 \mathrm{mmol} /$ $\mathrm{mol}$ to $9.50 \mathrm{mmol} / \mathrm{mol}$ (Figure $2 \mathrm{a}$ ) over the 218 -year record. Interannual growth rates range from $1.2 \mathrm{~mm} / \mathrm{a}$ to $5.9 \mathrm{~mm} / \mathrm{a}$, with only six years falling below $2 \mathrm{~mm} / \mathrm{a}$ and one year falling below $1.5 \mathrm{~mm} / \mathrm{a}$. Four of these years occur between 1840 and 1860, the period evaluated as the end of the LIA. Because we know that growth rates influence $\mathrm{Sr} / \mathrm{Ca}$ when sampled by this method, it could be hypothesized that reconstructed cooling between the 1840 s and $1850 \mathrm{~s}$ is an artifact of growth rate impacts. However, there is evidence that this is not the case. Equally high $\mathrm{Sr} / \mathrm{Ca}$ values (and low reconstructed temperatures) are seen in the $1820 \mathrm{~s}$, when growth rates fall above the average value, and other periods of below average growth rates (1890s, 1900s, 1920s and 1930s) do not show similarly high $\mathrm{Sr} / \mathrm{Ca}$ (low reconstructed temperatures) (Figures $2 \mathrm{a}$ and $2 \mathrm{~b}$ ). The veracity of the trends found in this reconstruction will be independently verified by examining wintertime $\mathrm{Sr} / \mathrm{Ca}$ (below), which has been shown to have no growth related impacts.

[20] Reconstructed mean annual temperature change at Bermuda exhibits both decadal and centennial-scale variability with a $5^{\circ} \mathrm{C}$ temperature range $\left(20.3^{\circ}-25.2^{\circ} \mathrm{C}\right)$. Temperature minima are found in the coral reconstruction at the

Table 1. Covariance $\left(\sigma^{2}\right)$ Among the Slopes and Intercept of the Multicolony, Growth-Corrected, Mean Annual Model ${ }^{\mathrm{a}}$

\begin{tabular}{lccc}
\hline & Intercept & SST & ag * SST \\
\hline SST & $-8.01 \times 10^{-3}$ & & \\
ag * SST & $9.57 \times 10^{-6}$ & $-1.09 \times 10^{-6}$ & \\
ig * SST & $-1.66 \times 10^{-5}$ & $5.48 \times 10^{-7}$ & $-8.79 \times 10^{-8}$ \\
\hline
\end{tabular}

${ }^{\mathrm{a}}$ See (equation (1)). Values were previously reported by Goodkin et al., [2007]. Definitions are ig, interannual growth rate; and ag, average growth rate. 

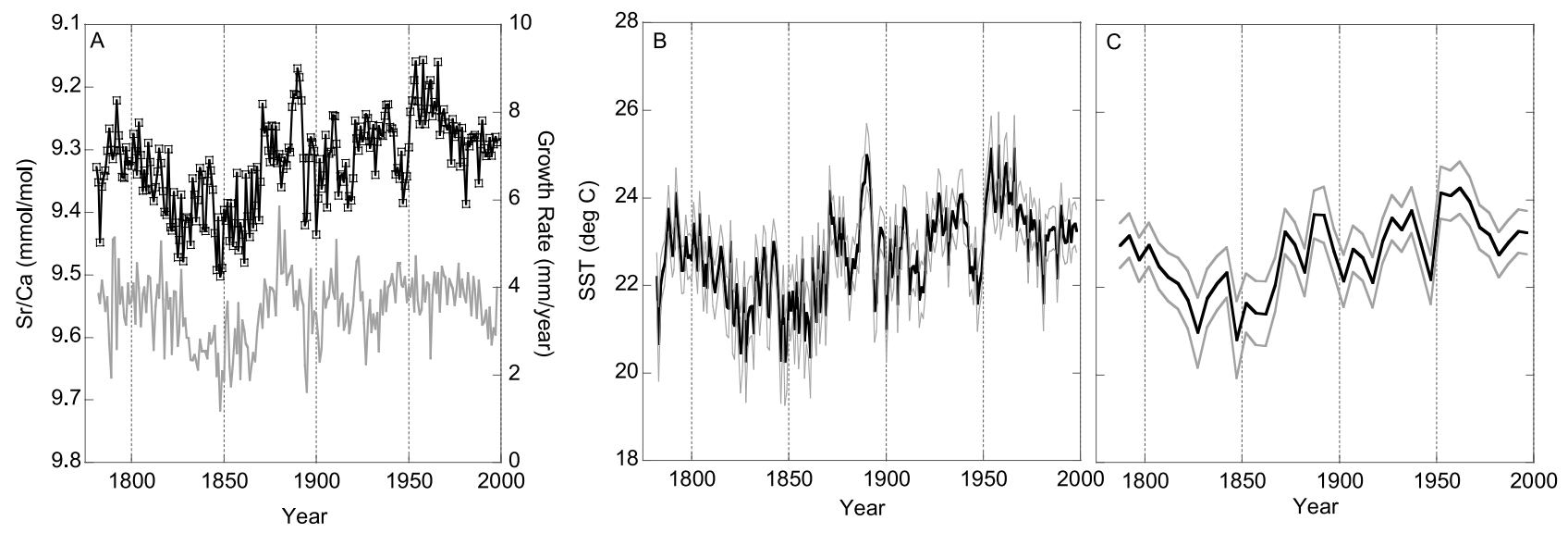

Figure 2. Mean annual geochemical, growth, and proxy SST results from a 218-year long record of brain coral from Bermuda. (a) Mean annual $\mathrm{Sr} / \mathrm{Ca}$ (solid line) and annual growth (extension) rate (shaded line) shown versus time. (b) Mean annual SST generated from $\mathrm{Sr} / \mathrm{Ca}$ (solid line) using the multicolony, growth-corrected calibration (equation (1)). Uncertainty $( \pm 1 \sigma)$ resulting from error propagation is shown with shaded lines. (c) Mean annual SST generated from $\mathrm{Sr} / \mathrm{Ca}$ binned into 5-year averages (solid line). Uncertainty $( \pm 1 \sigma)$ is shown with shaded lines.

end of the LIA around 1840 and 1850 (Figures $2 \mathrm{~b}$ and $2 \mathrm{c}$ ). The $\mathrm{Sr} / \mathrm{Ca}$-based reconstruction of SST shows the LIA (1840s) to be cooler than today (1990s instrumental average), at a statistically significant level of $1.7^{\circ} \mathrm{C} \pm 0.6^{\circ} \mathrm{C}$ cooler (Figure 3a). The largest temperature change $\left(2.6^{\circ} \mathrm{C} \pm\right.$ $0.6^{\circ} \mathrm{C}$ ) occurred in the reconstructed SST record between the $1840 \mathrm{~s}$ and $1960 \mathrm{~s}$.

\subsubsection{Winter Reconstruction}

[21] Winter $\mathrm{Sr} / \mathrm{Ca}$ generated by sampling methods used here has previously been shown to be correlated to SST irrespective of growth rate influences [Goodkin et al., 2005]. Appendix A in Text S1 in the auxiliary material presents detailed winter calibrations which confirm this result. ${ }^{1}$ A record of winter-SST in 5-year binned averages is generated by the following equation (equation (A2) in Table S1):

$$
\begin{aligned}
& \mathrm{Sr} / \mathrm{Ca}=-0.0972( \pm 0.0531) * \mathrm{SST}+11.3( \pm 1.1) \\
& \left(2 \sigma, 95 \% \text { conf., } \mathrm{r}^{2}=0.36, \mathrm{~F}_{\text {sig }}=0.0012, \mathrm{rmsr}=0.4^{\circ} \mathrm{C},\right. \\
& \left.\mathrm{se}=0.0036 \mathrm{mmol} / \mathrm{mol}, . \sigma^{2}=-0.014\right)
\end{aligned}
$$

where $\sigma^{2}$ is the covariance of the slope and intercept. After applying equation (2) to the winter $\mathrm{Sr} / \mathrm{Ca}$ data averaged in 5-year bins, the reconstructed winter SST is $18.6^{\circ} \mathrm{C}$ at the end of the LIA (1840s) and $21^{\circ} \mathrm{C}$ for late twentieth century maximum (1960s), statistically significant warming of $2.4^{\circ} \pm 0.4^{\circ} \mathrm{C}$ (Figure $3 \mathrm{~b}$ ). The end of the LIA is also shown to be $1.5^{\circ} \pm 0.4^{\circ} \mathrm{C}$ colder than the 1990 s instrumental average. The uncertainty reported here is the maximum independent value for each individual data point, a conservative estimate of uncertainty. However, averaging

${ }^{1}$ Auxiliary materials are available in the HTML. doi:10.1029/ 2007PA001532. changes over multiple data points (as done here) could reduce the uncertainty by $1 / \mathrm{n}^{1 / 2}$.

[22] The wintertime reconstruction without influence from growth rate has similar trends as the mean annual record (both in 5-year binned averages) (Figure 3). Much like the mean annual record, the warmest winters are seen in the 1960s and the coldest winters are seen between 1840 and 1860 (Figure 3b). The winter reconstruction has consistently cold temperatures from 1820 to 1860 , whereas the mean annual record shows a relative warming in the late 1830s. In general, the mean annual record shows increased variability (range of $3^{\circ} \mathrm{C}$ ) relative to the winter record $\left(2.5^{\circ} \mathrm{C}\right.$ range); however, the trends are in good agreement $(r=0.90)$. Differences between the wintertime and the mean annual record are not unexpected. For example, winter temperatures at Bermuda are influenced by the NAO [e.g., Visbeck et al., 2003] and are characterized by deep mixed layers and the formation of 18 degree mode water. Summer surface temperatures, in contrast, are characterized by shallow $(<20 \mathrm{~m})$ mixed layers strongly influenced by atmospheric forcing (ex. solar irradiance, wind induced mixing) and have not been shown to be influenced by the NAO. Therefore, a difference in the magnitude of temperature variability and the subdecadal trends between the winter and mean annual record are not implausible.

\subsubsection{Comparison to Instrumental Hydrostation $S$} and HadISST SST Records

[23] Comparing both the mean annual and the wintertime coral reconstructed SST to HadISST $\left(1^{\circ} \times 2^{\circ}\right.$ grid $)$ and Hydrostation $\mathrm{S}$ in 5 -year bins over the past 50 years shows increased variability in the coral records relative to the instrumental records (Figure 3, bottom plots). Mean annual SSTs from Hydrostation S, HadISST (gridded data), and the $\mathrm{Sr} / \mathrm{Ca}$ reconstruction agree well after 1970; prior to 1970 the reconstructed SSTs were on average higher than the HadISST and Hydrostation S SST records, with root mean 

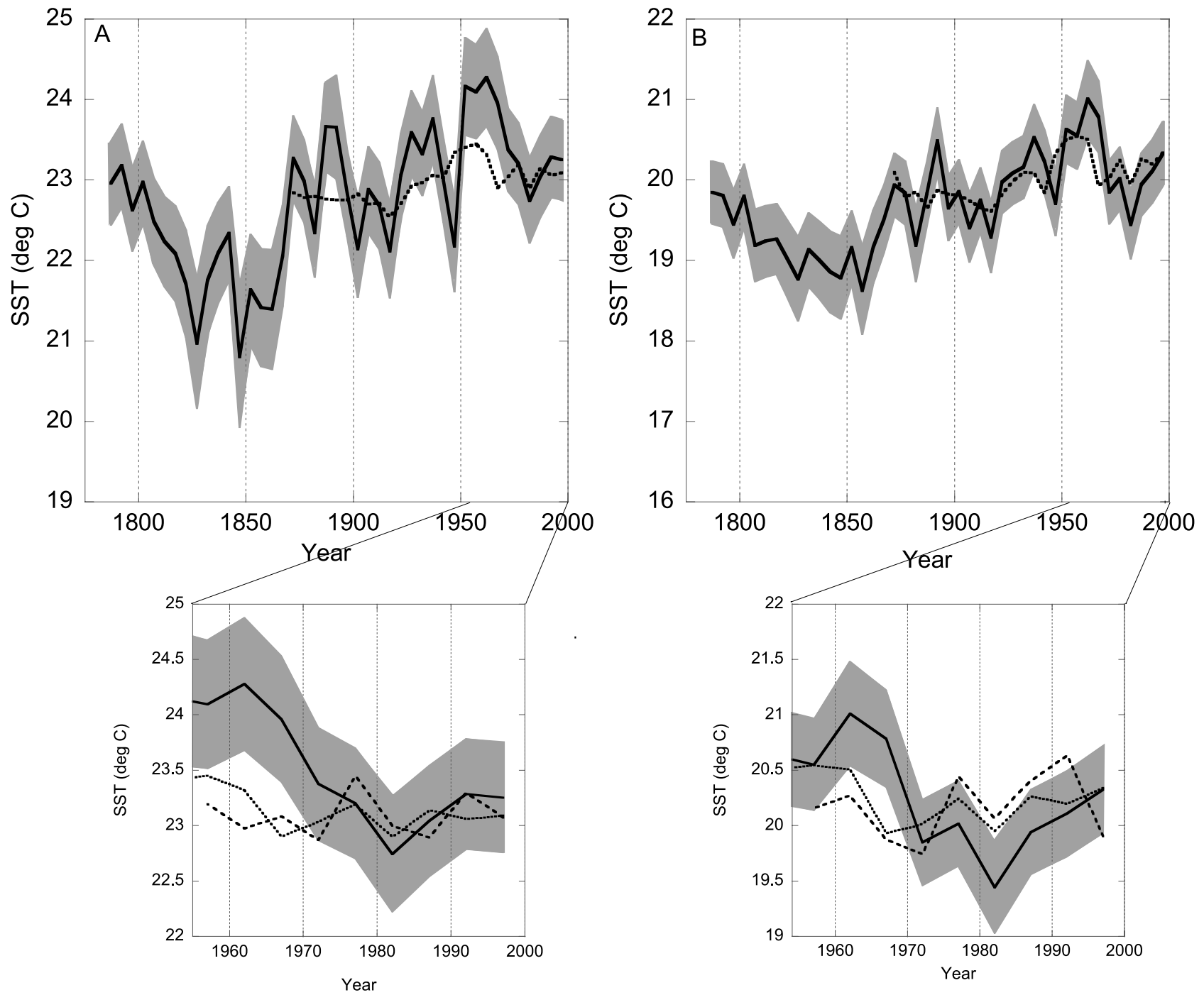

Figure 3. Coral-based reconstructed SST from Bermuda (solid line) compared to HadISST from a gridded area surrounding Bermuda (top and bottom, dotted line) and to Hydrostation S SST (bottom, dashed line). (a) Five-year average mean annual SST and (b) 5-year averaged winter SST. Coral reconstructed mean annual and winter SST are shown with propagated error $( \pm 1 \sigma)$ (shaded area).

squares of the residuals (rmsr) of $0.9^{\circ} \pm 0.6^{\circ}$ and $1.0^{\circ} \pm$ $0.6^{\circ} \mathrm{C}$, respectively (Figure $3 \mathrm{a}$, bottom).

[24] The winter reconstruction from 1954 to 1997 does not allow for an independent comparison between the coral and HadISST records because the coral is calibrated to HadISST over its entire length. However, while the discrepancies between the winter coral record and the instrumental records increase for 1954-1970 relative to 1970-1997 (rmsr compared to HadISST shifts from $0.3 \pm 0.4$ to $0.6 \pm$ 0.4 , and rmsr compared to Hydrostation $\mathrm{S}$ shifts from $0.5^{\circ} \pm$ $0.4^{\circ}$ to $0.7^{\circ} \pm 0.4^{\circ} \mathrm{C}$ ), a clear split in behavior similar to the mean annual coral record is not seen. In fact, Hydrostation $\mathrm{S}$ data fall outside the window of uncertainty of the winter coral record both before and after 1970. The differences in offsets between instrumental SST and coral reconstructions likely results from the different method used in the winter calibration, which excludes growth, increases the length of the calibration, and uses 5-year averages.

[25] In addition, differences seen among the two instrumental records and the coral (Figure 3, bottom plots) may also be due to several other factors. In particular, prior to 1975, Hydrostation S generally only has one measurement in the top $16 \mathrm{~m}$ (at $1 \mathrm{~m}$ depth), whereas after 1975 the majority of years have at least two measured depths in the top $16 \mathrm{~m}$ (most often $1 \mathrm{~m}$ and $10 \mathrm{~m}$ ), changing the composition of this record. The disagreement in trends among all mean annual records prior to 1970 also may reflect several additional factors: changes in upper water column stratification, changes in the shallow waters at Bermuda that are not representative of open ocean waters, changes in SST measurement protocols, or undiagnosed coral vital effects not present during the calibration period. The last effect is likely minor, however, as there is not a 
large or systematic change in the coral interannual growth rates between these two periods (average 1954-1970= $3.9 \mathrm{~mm} / \mathrm{a}$, average $1971-1997=3.7 \mathrm{~mm} / \mathrm{a}$ ) (Figure $2 \mathrm{a}$ ).

[26] In addition to the discrepancies seen in the last 50 years of the record, the mean annual reconstructed SSTs show up to 2 times more $\left(\sim 1^{\circ}\right.$ versus $\sim 2^{\circ} \mathrm{C}$ for the mean annual) interannual-to-decadal temperature variability relative to the gridded data set (Figure 3a, top). The greater variability in the mean annual SST reconstructions may imply a coral bias to overestimate temperature variations, including the amplitude of the temperature minimum at the end of the LIA. However, the multidecadal SST means and trends are relatively consistent between the coral reconstructions and the instrumental gridded data, and the persistence of the LIA temperature minimum for multiple decades in the coral record would argue that it is a robust feature. The root mean square of the residuals (rmsr) between the 5-year binned coral and HadISST records for the mean annual and wintertime is $0.6^{\circ} \mathrm{C}$ and $0.4^{\circ} \mathrm{C}$, respectively. Both of these residuals are within the uncertainty of the reconstructed coral record and significantly smaller than the reconstructed SST change from the end of the LIA to today $\left(1.5^{\circ} \mathrm{C}\right)$. In the winter records, single point differences exceed the error windows of the coral record for $27 \%$ of the points, and this happens for two consecutive points only during the $1950 \mathrm{~s}-1960$ s excursion. Our ultimate estimate of LIA temperature change is calculated from multiple points in the 5-year averaged record, and the rmsr between HadISST and the coral record does not exceed the error bounds. We therefore believe that the quantification of LIA temperature change is robust.

[27] There are several potential explanations for the temperature differences observed between the HadISST instrumental data and the reconstructed coral SST records. The first is the spatial difference between the two records. The coral is reconstructing a single point at depth whereas the HadISST instrumental data set is composed of multiple, surface observations over a large spatial domain $\left(2^{\circ}\right.$ by $1^{\circ}$ grid). Differences seen in the HadISST and Hydrostation S record support this idea. The representation error for using a single coral proxy record as a measure of the regional climate signal could introduce differences. A compilation of multiple offshore water measurements will average out variability found in a single location. In addition, the instrumental data are generally collected from offshore waters rather than shallow coastal waters where the coral grew, that are susceptible to factors such as upwelling due to close proximity to a landmass. Additionally, mesoscale eddy processes exert a large influence in this region [Doney, 1996; Sweeney et al., 2003]. Three types of eddies are found in the vicinity of Bermuda supplying both positive and negative near-surface temperature anomalies. A $2^{\circ}$ by $1^{\circ}$ grid box could effectively smooth eddy temperature anomalies, whereas eddies passing by the coral site over a several month period would produce substantial variability in SST.

[28] Second, the differences may arise because HadISST is measuring near-surface temperature (upper few meters depending upon the sampling method), and the coral reconstruction reflects temperatures at the coral growth depth of $16 \mathrm{~m}$. In essence, the two records are not measur- ing the same quantity. Coral and instrumental records can also be decoupled in the summer when the mixed layer can become very shallow $(<10 \mathrm{~m})$. The calibration method incorporates this effect to the extent that seasonal vertical stratification remains approximately constant through time. However, shifts in the summer vertical stratification on interannual to multidecadal timescales [Doney, 1996] could result in observed differences between the coral and instrumental record. This is of less concern in the winter when the mixed layer is deep $(>150 \mathrm{~m})$, and wintertime instrumental versus coral temperature differences should be less evident (and indeed are observed to be smaller). Difference in the agreement of the two instrumental records and the coral records that are not consistent between the winter and mean annual records support this hypothesis.

[29] Finally, both records have independent sources of error lessening the significance of temperature differences. The coral error has previously been discussed, and these errors include: growth rate impacts on coral $\mathrm{Sr} / \mathrm{Ca}$ not accounted for in the calibrations; changing impacts of bulk sampling through time impacting the resolution of the coral record; and finally small changes in $\mathrm{Sr}$ and $\mathrm{Ca}$ concentrations in seawater resulting from a combination of biological and upwelling processes [Bernstein et al., 1987; Culkin and Cox, 1966], which should be significantly smaller than the changes in $\mathrm{Sr} / \mathrm{Ca}$ seen here. The instrumental records have several sources of error typical of such data sets [Jones et al., 1997, 2001; Rayner et al., 2003], including error introduced from changing technology through time, nonequal distribution of the number and location of measurements made throughout each year and throughout the grid, and varying numbers of samples within the grid through time.

[30] Although there are concerns as discussed above, we believe that the coral $\mathrm{Sr} / \mathrm{Ca}-\mathrm{SST}$ reconstructions, particularly for winter, used in this study are robust. Research has shown that calibration error tends to exaggerate reconstructed temperature change rather than minimize it [Goodkin et al., 2005; Swart et al., 2002]. This is reinforced by the increased variability seen here in the coral reconstructions relative to the gridded data. However, both the mean annual and wintertime records have similar patterns of variability, following different calibration approaches. The reconstructed coral SSTs show mean annual and winter temperature changes of $1.5^{\circ} \mathrm{C}$ between the LIA and the 1990 s instrumental records. Error propagation suggests these changes are statistically significant. In addition, many of the specific discrepancies between the coral and instrumental records may be real, recording differences between what the coral experienced locally and what the ocean experienced regionally. This distinction is important for interpreting these results in terms of regional climate change.

\subsection{The $\delta^{18} \mathrm{O}-\mathrm{SSS}$}

[31] The $\delta^{18} \mathrm{O}$ of the coral aragonite $\left(\delta \mathrm{O}_{\mathrm{c}}\right)$ has a negative correlation to $\mathrm{SST}$ and positive correlation to $\mathrm{SSS}$, as expected (Appendix B in Text S2 of auxiliary material). In Text S2, we show that with the present coral record and relatively short calibration data set, we are unable to derive a robust, statistically significant separation of the salinity 

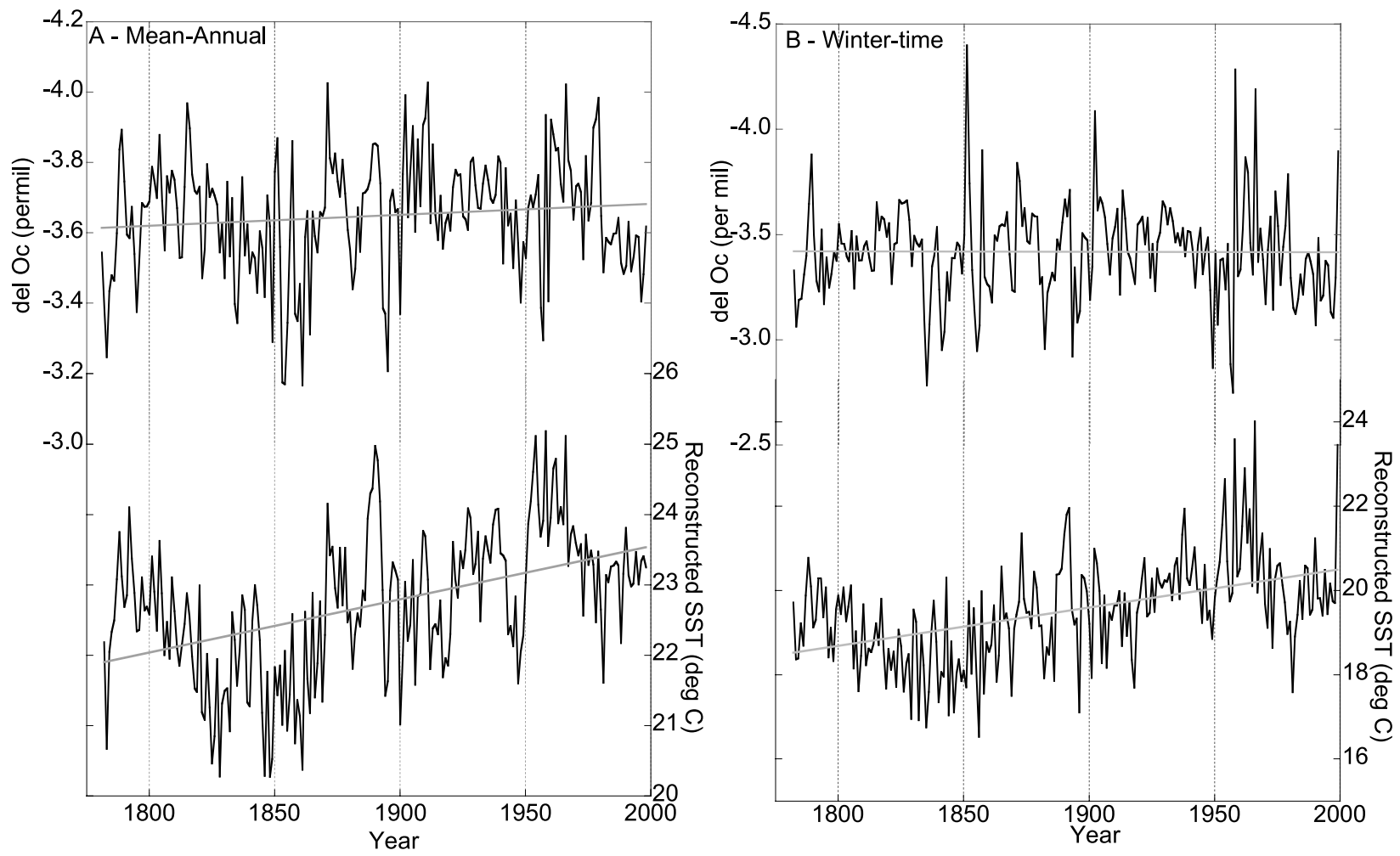

Figure 4. The $\delta \mathrm{O}_{\mathrm{c}}$ and reconstructed SST records versus time from 1781 to 1997 from a Bermuda coral. (a) Mean annual record. SST is generated from equation (1). (b) Wintertime record. Annual SST is generated from equation (A1) in Table S1 of auxiliary material. Linear regressions of each parameter versus time are shown by shaded lines.

and temperature signals within the coral $\delta^{18} \mathrm{O}$. There are several factors that may prevent the quantification of these relationships, the most likely being the lack of large changes in SSS documented in the instrumental data. Over the length of the Hydrostation S record, salinity (mean annual and winter) has a range of only $0.3 \mathrm{psu}$, too small to establish a significant relationship for these proxies, given representation error (noise) in the coral and instrumental records.

[32] There are also several factors that may be adding variability to the system that given the small SSS signal makes calibration more difficult. As previously discussed with regard to regional SST records, eddy activity in the region also contributes to salinity variations [Doney, 1996]. Eddies could lead to differences between SSS at the coral and Hydrostation S locations, thus adding unexplained variability over the limited calibration period. Vital effects linked to growth may be causing varying fractionation of $\delta \mathrm{O}_{\mathrm{c}}$ during the calibration period, and bulk sampling could be compounding these signals. While we were unable to model such effects, if they exist they could further mask the SSS signal. In the end, we are unable to quantitatively reconstruct salinity using coral $\delta^{18} \mathrm{O}$ and $\mathrm{Sr} / \mathrm{Ca}$ proxies.

[33] However, the long-term trends in the raw $\delta^{18} \mathrm{O}$ and $\mathrm{Sr} / \mathrm{Ca}$ data provide a strong indication that the ocean surface waters near Bermuda were fresher during the LIA, even if we cannot quantitatively partition the temperature and salinity signals. Over the course of the 200-year record, long-term trends in mean annual and wintertime $\delta \mathrm{O}_{\mathrm{c}}$ $(-0.0003 \%$ o $/ \mathrm{a}$ and $<0.0001 \%$ /a, respectively) are effectively flat (Figures $4 \mathrm{a}$ and $4 \mathrm{~b}$ ). Simultaneously, both mean annual and wintertime $\mathrm{Sr} / \mathrm{Ca}$-based SST show increasing temperatures through time $\left(0.008^{\circ} \mathrm{C} / \mathrm{a}\right.$ and $0.009^{\circ} \mathrm{C} / \mathrm{a}$, respectively) (Figures $4 \mathrm{a}$ and $4 \mathrm{~b}$ ). If $\delta \mathrm{O}_{\mathrm{c}}$ were purely a result of SST, and SST is increasing through time, a strong negative trend would be visible in the $\delta \mathrm{O}_{\mathrm{c}}$ records [McConnaughey, 1989a, 1989b]. The isotopic composition of biogenic aragonite from measurements of noncoral species (foraminifera, gastropods, and scaphopods) has been expressed as a function of temperature [Grossman and $\mathrm{Ku}, 1986]$ :

$$
\delta \mathrm{O}_{\mathrm{c}}-\delta \mathrm{O}_{\mathrm{w}}=-0.23 *(\mathrm{SST})+4.75
$$

[34] Given the increasing temperature through time seen in both the SST reconstructions and the slope of $-0.23 \%$ / ${ }^{\circ} \mathrm{C}$ predicted by Grossman and $K u$ [1986], the trends of $\delta \mathrm{O}_{\mathrm{c}}$ versus time would be an order of magnitude steeper than seen for the mean annual $\delta \mathrm{O}_{\mathrm{c}}$ data, and the winter trend would have the opposite sign (both $-0.002 \%$ a). In addition, a strong LIA cooling is seen in both $\mathrm{Sr} / \mathrm{Ca}$-generated SST records, whereas the mean annual and wintertime $\delta \mathrm{O}_{\mathrm{c}}$ show no (or minimal) indication of this cooling. The relationship between $\delta \mathrm{O}_{\mathrm{w}}$ and $\mathrm{SSS}$ within the thermocline and within this region has been found to be $0.49 \%$ o $/$ salinity unit [Goodkin, 2007; G. A. Schmidt, Global Seawater 
Oxygen-18 Database, 1999, available at http://data.giss. nasa.gov/o18data/]. Incorporating this relationship into equation (3) and solving for a change in SSS for the 150 years from 1840 to 1990 estimates a salinity increase on the order of $0.6 \mathrm{psu}$ from the end of the LIA to the end of the twentieth century.

\section{Discussion}

[35] In this paper, we have developed two reconstructions of SST for the last two centuries from a Bermuda brain coral. The mean annual reconstruction is generated from mean annual $\mathrm{Sr} / \mathrm{Ca}$, mean annual growth rates and average colony growth rate; the wintertime SST reconstruction is generated using only wintertime $\mathrm{Sr} / \mathrm{Ca}$. The wintertime reconstruction shows no apparent growth effects and a $\mathrm{Sr} /$ $\mathrm{Ca}-\mathrm{SST}$ slope in agreement with a laser ablation study which is free of bulk sampling complications [Cohen and Thorrold, 2007]. These results support the winter record as the less complicated of the two reconstructions. However, because the wintertime coral SST record is reconstructed in 5 -year bins, the mean annual record will be used for quantitative comparisons of patterns to potential forcing mechanisms.

[36] The $\delta^{18} \mathrm{O}$ records combined with the SST reconstructions demonstrates that salinity generally increased on the order of 0.6 psu from the end of the LIA to today, in both the wintertime and mean annual results. The temperature and salinity signals extracted from the coral will now be compared to other reconstructions from the North Atlantic region and compared to potential forcing mechanisms.

\subsection{Climate and Ocean Trends at Bermuda}

[37] The Bermuda coral $\mathrm{Sr} / \mathrm{Ca}$ and $\delta^{18} \mathrm{O}_{\mathrm{c}}$ records show that surface waters at the end of the LIA were about $1.5^{\circ} \mathrm{C}$ cooler and likely fresher than at the end of the twentieth century. Temperature trends at Bermuda from this study are in good agreement with trends from other Bermuda coral records. Draschba et al. [2000] show maximum coral $\delta^{18} \mathrm{O}$ of $\sim-3.2 \%$ (minimum temperature) from 1840 to 1845 and $\sim 1855$ and minimum $\delta^{18} \mathrm{O}$ of $\sim-3.7 \%$ o (maximum temperature) at $\sim 1870$, similar to trends and mean annual $\delta^{18} \mathrm{O}$ values seen in this study (Figure 4). A foraminiferal $\delta^{18} \mathrm{O}$ temperature reconstruction from the Bermuda Rise sediment drift shows a temperature increase of $1.5^{\circ} \mathrm{C}$ from the LIA to the end of the twentieth century [Keigwin, 1996], in agreement with the statistically significant change $\left(\sim 1.5^{\circ} \mathrm{C}\right)$ found here for both the mean annual and wintertime SST reconstructions (Figure 3).

[38] The temperature and salinity trends are also similar to trends from 1890 to 1990 found in a sclerosponge record collected off the Bahamas (140 m depth) that demonstrate both increasing temperature $\left(1.6^{\circ}-2.0^{\circ} \mathrm{C}\right)$ and salinity ( $\sim 1 \mathrm{psu}$ ) [Rosenheim et al., 2005]. Another study from the Bahamas using foraminifera to reconstruct salinity records from the eastern side of the Florida Current generally shows increasing salinity since the LIA [Lund and Curry, 2006].

[39] Several records of SST from proxy reconstructions exist from a variety of other subtropical locations across the Atlantic. Two coral records near Puerto Rico reconstruct temperature increases in the Caribbean Sea of $2^{\circ}-3^{\circ} \mathrm{C}$ since the end of the LIA [Watanabe et al., 2001; Winter et al., 2000]. A foraminifera-based reconstruction in the eastern subtropical Atlantic records larger SST changes (on the order of $3^{\circ}-4^{\circ} \mathrm{C}$ ) from the LIA to present [deMenocal et al., 2000]. Combined, all of these single-location records show that the subtropical gyre in the midlatitudes experienced a large temperature increase between the end of the LIA and today.

[40] Regional surface temperature records from the Northern Hemisphere [Jones et al., 1998] and Arctic [Overpeck et al., 1997], all smoothed over 30 years using a running mean, show a somewhat lower magnitude of total temperature change from the minimum in the $1840 \mathrm{~s}$ to the maximum in the $1950 \mathrm{~s}-1960 \mathrm{~s}\left(\sim 1^{\circ} \mathrm{C}\right)$, compared to the mean annual coral record $\left(2.0^{\circ} \mathrm{C}\right)$ (Figure 5). The wintertime record is closer in magnitude to the regional records, with a maximum change of $1.6^{\circ} \mathrm{C}$. However, these spatial syntheses and the coral records all show very similar patterns of increasing temperature from the LIA to present. Correlation coefficients between the $\mathrm{Sr} / \mathrm{Ca}$-derived mean annual SST record and the Arctic and Northern Hemisphere records are 0.40 and 0.47 , respectively. Each of the records exhibits minimum temperatures at the end of the LIA, between 1800 and 1850 , followed by warming to maximum averaged temperatures in the 1950s and 1960s. Two cool periods are seen in the mean annual coral and regional records during the early 1800 s, with an offset of $\sim 10$ years in timing between the coral records and the atmospheric records. We believe this is possibly related to a combination of cumulative age model error through time in the coral record and a delayed ocean response to atmospheric cooling. A pronounced drop in temperature in the $1970 \mathrm{~s}$ following the peak warmth (1960) is apparent, primarily in the Bermuda and Arctic records (Figure 5), locations both strongly influenced by the NAO and Arctic Oscillation (AO). These climate modes can cause decadal-scale temperature trends which will dominate temperature signals on these timescales. Note that our Bermuda coral was collected in 2000 and thus would not capture the most recent elevated Northern Hemisphere and global temperatures seen since 2000.

[41] Smoothing the regional and coral records with a 30 -year box filter reveals strong coherence in the timing of temperature changes of the past 200 years (Figure 5). One notable discrepancy between the records occurs between 1870 and 1900, when the Bermuda records show warming occurring earlier than in the other records. The agreement between the smoothed regional records and coral reconstructions is highly significant, with correlation coefficients of 0.86 between the mean annual coral record and each regional synthesis. The increase in correlation for the smoothed records relative to the interannual records ( 0.47 to Overpeck et al. [1997] and 0.40 to Jones et al. [1998]) highlights that most of the agreement is in the multidecadal trends, which may result from the diminishing impact of age model uncertainty over longer windows. While all of the records show cooling in the mid-1800s consistent with a Northern Hemisphere-wide response (possibly because of radiative forcing, see below), the range of temperature changes suggest differing regional and local responses that may be 


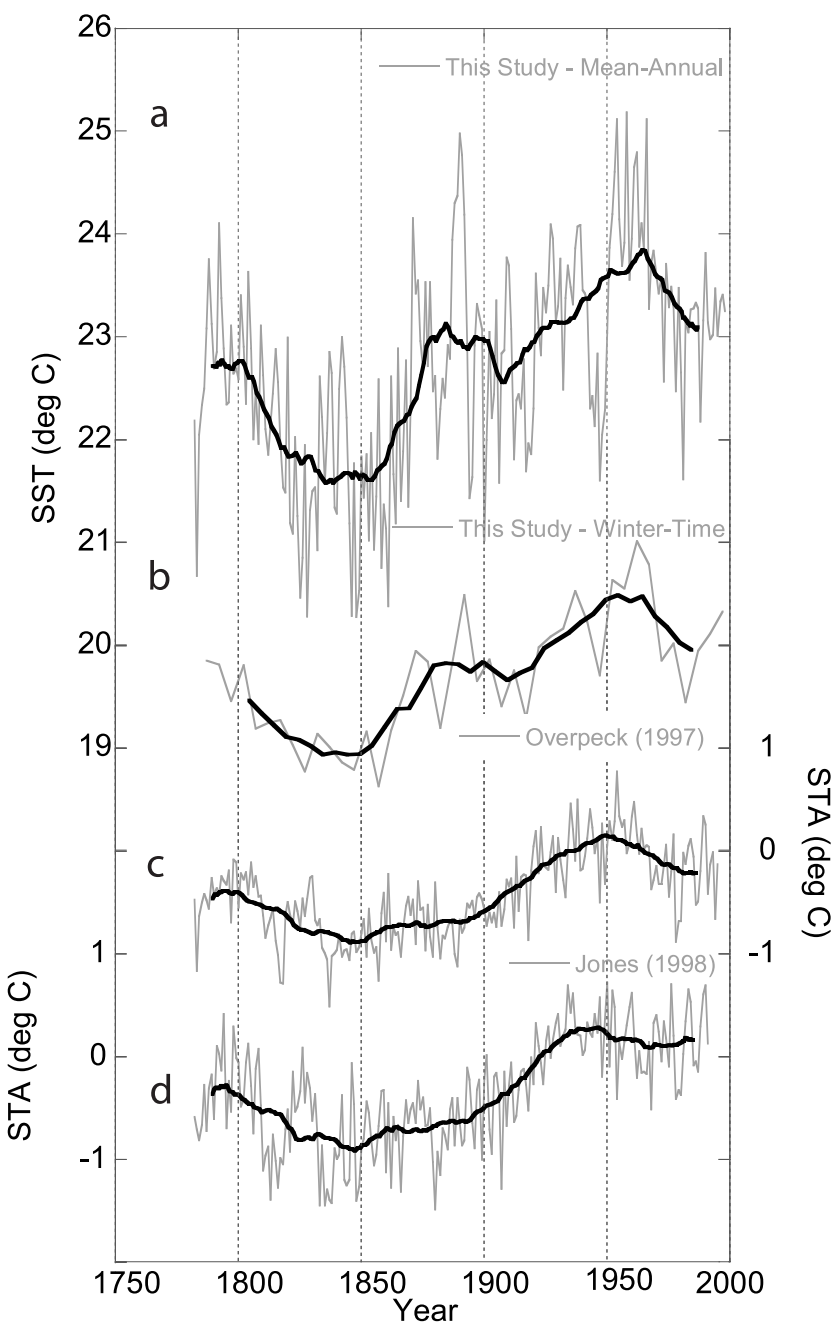

Figure 5. Mean annual (annual) and winter (5 years) reconstructed SST from coral $\mathrm{Sr} / \mathrm{Ca}$, Arctic land reconstructed surface temperature record [Overpeck et al., 1997], and Northern Hemisphere land reconstructed surface temperature record [Jones et al., 1998] (all shaded lines) and then filtered over 30 years (solid lines). Mean annual and wintertime coral reconstructions ( $\mathrm{a}$ and $\mathrm{b}$ ) compared to both the Overpeck et al. [1997] (c) for mean annual record $(\mathrm{r}=0.40)$ and to the Jones et al. [1998] (d) for mean annual record $(\mathrm{r}=0.47)$. The structure of the coral reconstruction as defined by the mean annual 30-year running average agrees with Overpeck et al. [1997] $(\mathrm{r}=0.86)$ and Jones et al. [1998] $(\mathrm{r}=0.86)$ after the low-pass filter despite a difference in the magnitude of the temperature change. The wintertime 30-year running mean has a maximum (point to point) temperature change of $1.6^{\circ} \mathrm{C} \pm 0.4^{\circ} \mathrm{C}$ in line with the two land-based records $\left(1.0^{\circ} \mathrm{C}\right.$ (Overpeck et al.) and $1.2^{\circ} \mathrm{C}$ (Jones et al.)).

due to processes such as changing ocean circulation and the NAO.

\subsection{Influences on Observed Variability}

[42] Temperature and salinity changes at Bermuda were likely caused by a combination of atmospheric forcing and ocean circulation changes. The largest events over the past 200 years were the end of LIA cooling and twentieth century warming, coupled with changes in salinity interpreted from the $\delta \mathrm{O}_{\mathrm{c}}$. Several possible influences may have contributed to these oceanographic changes, including anthropogenic, solar and volcanic forcing. Each of these would be expected to generate regional to hemispheric and global impacts. In contrast, variations in the strength of the Gulf Stream and the relative influence of tropical, subpolar, and subtropical gyre waters would have more local influences [Lund et al., 2006; Talley, 1996]. Finally, the NAO is hypothesized to have had a large influence on the climate of the North Atlantic Basin from the time of the LIA to the modern day [Luterbacher et al., 1999], and may have contributed to the differences in reconstructed temperature patterns seen throughout the Atlantic [Goodkin, 2007]. Local changes in ocean vertical mixing rates may also be a critical factor affecting SST at Bermuda [Druffel, 1997].

[43] With respect to records of atmospheric and ocean forcing, multiple mechanisms appear to have potential to influence surface temperature at Bermuda. Coral reconstructed mean annual SST is positively correlated to a proxy reconstruction of solar activity from Lean et al. [1995] ( $\mathrm{r}=$ 0.34) (Figure 6). Cross-spectral analysis comparing mean annual coral reconstructed SST to solar variability, using a multitaper method with 10 windows (P. Huybers, Multitaper method coherence using adaptive weighting and correcting for the bias inherent to coherence estimates, http://www.people.fas.harvard.edu/ phuybers/Mfiles/ index.html, 2003), shows significant correlation at subdecadal and multidecadal frequencies $(2.5$ years per cycle, $\mathrm{r}=$ 0.55 and $>20$ years per cycle, $r>0.45$, respectively). At low frequencies the two records are in phase with one another, whereas at high frequencies reconstructed SST lags the estimated solar forcing. The lag at high frequencies is likely a combination of the heat capacity of seawater and the finite timescales for ocean mixing and circulation, which could all serve to dampen the oceanic response to atmospheric forcing. Potential bias in the coral age model could also contribute.

[44] A sharp decline in estimated solar forcing, which begins in the 1790s and continues until the 1830 s, coincides with the beginning of late LIA cooling seen in the coral record. However, the lowest SST temperatures are seen after the solar flux begins to return to pre-1790 values. Estimated solar activity and SST both reach maximum values in the late 1950s, although solar activity shows two more maxima in the 1980s-1990s, and SSTs do not exhibit maxima during these periods [Crowley, 2000] (Figure 6).

[45] Volcanic activity is believed to cause decreased surface temperatures for $2-4$ years posteruption, depending on size and location of the event, because of ash and $\mathrm{SO}_{2}$ in the atmosphere blocking solar radiation [e.g., Wigley et al., 2005]. This relationship is supported by minimum temperatures at Bermuda during and following times of increased volcanic activity (Figure 6). In particular, cooler temperatures occur in the Bermuda coral record and Arctic record of Overpeck et al. [1997] at the end of the twentieth century, a time of increased anthropogenic forcing [e.g., Hansen et al., 2006; Intergovernmental Panel on Climate Change, 


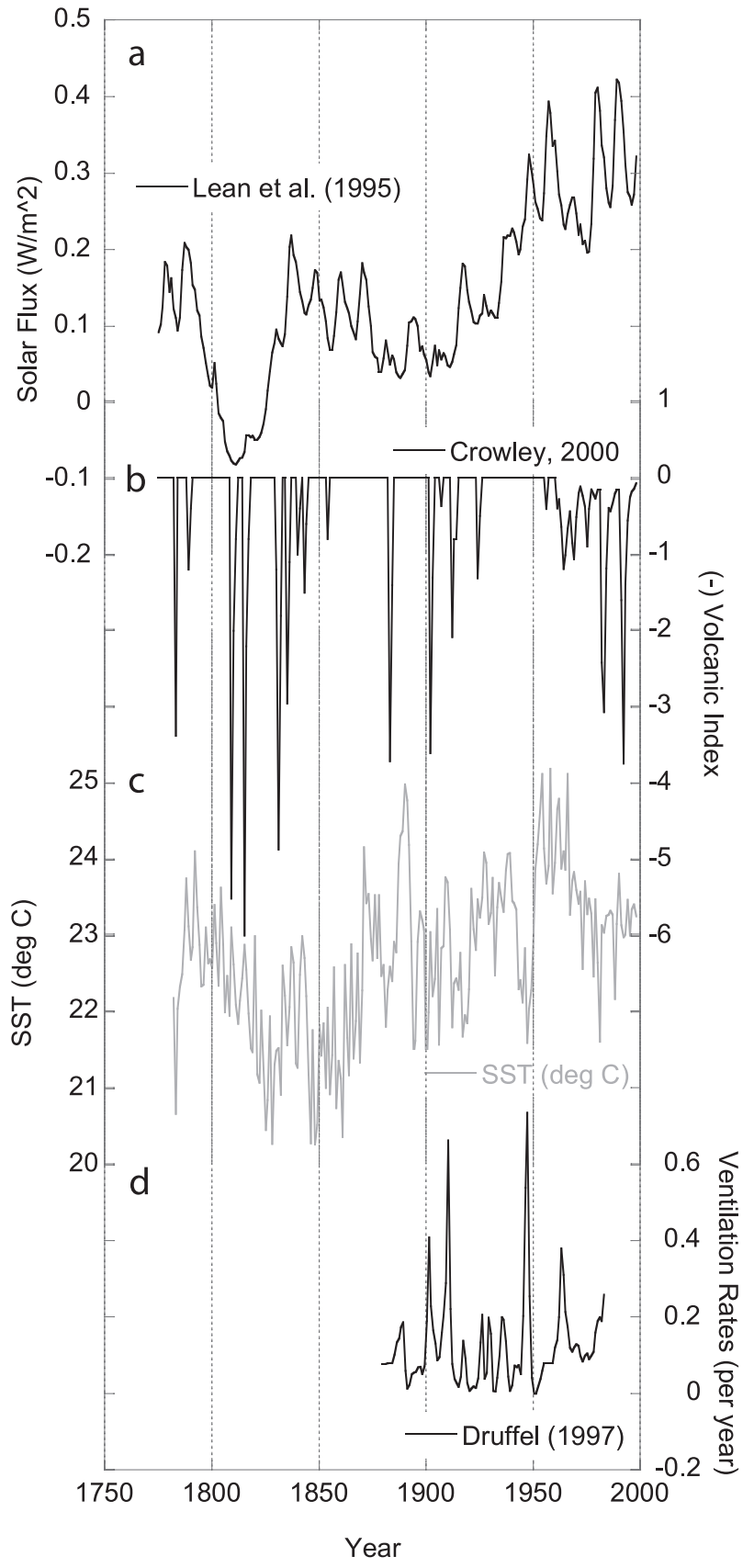

Figure 6. Records of potential forcing influences on temperature compared to reconstructed SST. (a) Annual solar flux $\left(\mathrm{W} / \mathrm{m}^{2}\right)$ proxy [Lean et al., 1995], (b) annual volcanic index $(\mathrm{x}(-1))$ [Crowley, 2000], (c) mean annual reconstructed SST (this record) $\left({ }^{\circ} \mathrm{C}\right)$, and $(\mathrm{d})$ mean annual reconstructed vertical mixing rates (per year) at Bermuda [Druffel, 1997].

2007] and solar activity. However, during this time an extended period of high to moderate volcanic activity was also observed and may have contributed to decreased temperatures [Crowley, 2000]. In addition, an increased volcanic index value [Crowley, 2000; Hammer et al., 1980; Overpeck et al., 1997] typically precedes sharp interannual temperature changes and occurs during extended decadal cooling at the end of the LIA from 1820 to 1860 . The lack of exact synchronicity between corals and forcing during these periods may be due to errors in the age model, which would lead to the reconstructed temperature drops occurring earlier in time and in closer proximity to the volcanic events.

[46] There is also evidence that increased vertical mixing rates at Bermuda may contribute to ocean temperature trends (Figure 6). Increased mixing entrains deeper, colder water into the surface mixed layer [Druffel, 1997]. Deep water, which has a lower $\Delta^{14} \mathrm{C}$ value than surface water, leaves a signal in Bermuda corals used to reconstruct deep water mixing. A high-frequency relationship is seen between periods of extended, elevated vertical mixing and similarly long periods of decreased temperatures (Figure 6), including the 1940s and late twentieth century. For the four times in the $\Delta^{14} \mathrm{C}$ record that the vertical mixing rate exceeds 0.4 per year, there are noticeably lower SSTs. Corresponding changes in salinity and SST implied by the $\delta \mathrm{O}_{\mathrm{c}}$ variability support the conclusion that vertical mixing is influencing the region, even if these changes are partially atmospherically driven.

[47] Finally, the NAO also influences surface water properties [Cayan, 1992; Dickson et al., 1996; Reverdin et al., 1997; Talley, 1996], including seawater temperature. During the end of the LIA from 1830 to 1860 , the NAO was in an extended positive phase (large difference between the pressure centers at Iceland and the Açores) [Luterbacher et al., 1999], which at low frequencies causes decreased temperatures at Bermuda [Visbeck et al., 2003]. Wintertime SST remained relatively low throughout this period, but mean annual SST shows larger variability including a warming in the 1830s-1840s. Filtering the Luterbacher et al. [1999] NAO record with a 5 -year box window shows a period of extended weak, positive NAO from the mid-1840s to $\sim 1880$, coincident with the second extended cooling of the $1800 \mathrm{~s}$.

\section{Conclusions}

[48] Quantitative calibration of coral skeletal $\mathrm{Sr} / \mathrm{Ca}$ to SST from the south shore of Bermuda resulted in reconstructions of mean annual and wintertime SST variability over the past two centuries. The SST records document the end of the LIA $(\sim 1850)$ with temperatures on the order of $\sim 1.5^{\circ} \mathrm{C}$ cooler than the late $1990 \mathrm{~s}$. The mean annual and wintertime SST records, combined with carbonate $\delta^{18} \mathrm{O}$, demonstrate generally lower surface salinity (fresher conditions) at the end of the LIA compared to today. SST changes in the coral record agree with foraminiferal records from the region, and radiative and atmospheric forcing can explain a portion of the SST variability. Disagreement with the gridded instrumental data set shows the coral to overestimate SST changes, with trends agreeing over multidecadal scales.

[49] Changes in SST and SSS not explained by atmospheric forcing and not seen in regional SST averages may indicate large-scale ocean circulation impacts as well. At depth $(>250 \mathrm{~m}$ and $<4000 \mathrm{~m})$, Hydrostation $\mathrm{S}$ shows that salinity decreases with decreasing temperatures. Therefore, 
the combined salinity and temperature signals would be consistent with increased ocean vertical mixing rates. The local coral signals may also have been driven by shifts in surface conditions, including heat flux, evaporation and precipitation, drive in turn by a shift in storm tracks related primarily to long-term variability in the NAO. Given the widespread scale of observed LIA cooling, however, changes in ocean circulation or the NAO are not likely to be the only cause, but may have locally enhanced the more regional atmospheric and radiative forcing.
[50] Acknowledgments. We are indebted to Anne Cohen (A.L.C.) for providing the coral samples and much information on how corals grow and to Mike McCartney (M.S.M.) for his support. Two anonymous reviewers greatly improved this manuscript. Thanks as well to S. Smith, G. Webster, S. du Putron, G. Piniak, J. Pitt, A. Solow, P. Huybers, D. Schrag, E. Boyle, C. Bertrand, P. Landry, and R. Kayser for logistical and technical help. A WHOI OCCI Fellowship (N.F.G.), and grants from NSF (OCE-0402728) and WHOI (N.F.G., K.A.H., A.L.C., and M.S.M.) supported this work.

\section{References}

Alibert, C., and M. T. McCulloch (1997), Strontium/calcium ratios in modern Porites corals from the Great Barrier Reef as a proxy for sea surface temperature: Calibration of the thermometer and monitoring of ENSO, Paleoceanography, 12, 345-363, doi:10.1029/97PA00318.

Beck, J. W., R. L. Edwards, E. Ito, F. W. Taylor, J. Recy, F. Rougerie, P. Joannot, and C. Henin (1992), Sea-surface temperature from coral skeletal strontium calcium ratios, Science, 257, 644-647, doi:10.1126/science.257.5070.644.

Beck, J. W., J. Recy, F. Taylor, R. L. Edwards, and G. Cabioch (1997), Abrupt changes in early Holocene tropical sea surface temperature derived from coral records, Nature, 385, 705-707, doi:10.1038/385705a0.

Bernstein, R. E., P. R. Betzer, R. A. Feely, R. H. Byrne, M. F. Lamb, and A. F. Michaels (1987), Acantharian fluxes and strontium to chlorinity ratios in the North Pacific Ocean, Science, 237, 1490-1494, doi:10.1126/science.237.4821.1490.

Bevington, P. R. (1969), Propagation of error, in Data Reduction and Error Analysis for the Physical Sciences, chap. 4, pp. 56-65, McGraw Hill, New York.

Bond, G., W. Showers, M. Cheseby, R. Lotti, P. Almasi, P. deMenocal, P. Priore, H. M. Cullen, I. Hajdas, and G. Bonani (1997), A pervasive millennial-scale cycle in North Atlantic Holocene and glacial climates, Science, 278, 1257-1266, doi:10.1126/ science.278.5341.1257.

Bradley, R. S., and P. D. Jones (1993), Little Ice Age summer temperature variations: Their nature and relevance to recent global warming trends, Holocene, 3, 367-376, doi:10.1177/ 095968369300300409.

Briffa, K. R., T. J. Osborn, F. H. Schweingruber, I. C. Harris, P. D. Jones, S. G. Shiyatov, and E. A. Vaganov (2001), Low-frequency temperature variations from a northern tree-ring density network, J. Geophys. Res., 106, 2929-2941, doi:10.1029/2000JD900617.

Cardinal, D., B. Hamelin, E. Bard, and J. Patzold (2001), $\mathrm{Sr} / \mathrm{Ca}, \mathrm{U} / \mathrm{Ca}$ and $\delta^{18} \mathrm{O}$ records in recent massive corals from Bermuda: Relationships with sea surface temperature, Chem. Geol., 176, 213-233, doi:10.1016/S0009-2541(00) 00396-X.

Cayan, D. (1992), Latent and sensible heat flux anomalies over the northern oceans: The connection to monthly atmospheric circulation, J. Clim., 5, 354-369, doi:10.1175/15200442[1992] 005<0354:LASHFA > 2.0.CO;2.

Cohen, A. L., and S. R. Hart (1997), The effect of colony topography on climate signals in coral skeleton, Geochim. Cosmochim. Acta, 61, 3905-3912, doi:10.1016/S0016-7037(97) 00200-7.
Cohen, A. L., and S. R. Thorrold (2007), Recovery of temperature records from slow-growing corals by fine scale sampling of skeletons, Geophys. Res. Lett., 34, L17706, doi:10.1029/2007GL030967.

Cohen, A. L., S. R. Smith, M. S. McCartney, and J. van Etten (2004), How brain corals record climate: An integration of skeletal structure, growth and chemistry of Diploria labyrinthiformis from Bermuda, Mar. Ecol. Prog. Ser. 271, 147-158, doi:10.3354/meps271147.

Crowley, T. J. (2000), Causes of climate change over the past 1000 years, Science, 289, 270 277, doi:10.1126/science.289.5477.270.

Culkin, F., and R. A. Cox (1966), Sodium, potassium, magnesium, calcium and strontium in seawater, Deep Sea Res. Oceanogr. Abstr. 13, 789-804.

Curry, R., R. Dickson, and I. Yashayaev (2003), A change in the freshwater balance of the Atlantic Ocean over the past four decades, Nature, 426, 826-829, doi:10.1038/ nature 02206

Dahl-Jensen, D., K. Mosegaard, N. Gunderstrup, G. D. Clow, A. W. Johnsen, A. W. Hansen, and N. Balling (1998), Past temperature directly from the Greenland Ice Sheet, Science, 282, 268-271, doi:10.1126/science.282.5387.268.

Dansgaard, W., S. J. Johnsen, N. Reeh, N. Gunderstrup, H. B. Clausen, and C. U. Hammer (1975), Climate changes, Norsemen, and modern man, Nature, 255, 24-28, doi:10.1038/255024a0.

deMenocal, P., J. Ortiz, T. Guilderson, and M. Sarnthein (2000), Coherent high- and lowlatitude climate variability during the Holocene warm period, Science, 288, 2198-2202, doi:10.1126/science.288.5474.2198

de Villiers, S., G. T. Shen, and B. K. Nelson (1994), The Sr/Ca-temperature relationship in coralline aragonite-Influence of variability in $(\mathrm{Sr} / \mathrm{Ca})_{\text {seawater }}$ and skeletal growth parameters, Geochim. Cosmochim. Acta, 58, 197-208, doi:10.1016/0016-7037(94)90457-X.

de Villiers, S., B. K. Nelson, and A. R. Chivas (1995), Biological controls on coral $\mathrm{Sr} / \mathrm{Ca}$ and $\delta^{18} \mathrm{O}$ reconstructions of sea surface temperatures, Science, 269, 1247-1249, doi:10.1126/ science.269.5228.1247.

Dickson, R., J. R. N. Lazier, J. Meincke, P. B Rhines, and J. Swift (1996), Long-term coordinated changes in the convective activity of the North Atlantic, Prog. Oceanogr., 38, $241-$ 295, doi:10.1016/S0079-6611(97)00002-5.

Doney, S. C. (1996), A synoptic atmospheric surface forcing data set and physical upper ocean model for the U.S. JGOFS Bermuda Atlantic Time-Series Study site, J. Geophys. Res., 101, 25,615-25,634, doi:10.1029/ 96JC01424.
Draschba, J., J. Patzold, and G. Wefer (2000) North Atlantic climate variability since AD 1350 recorded in $\delta^{18} \mathrm{O}$ and skeletal density of Bermuda corals, Int. J. Earth Sci., 88, 733741, doi:10.1007/s005310050301.

Druffel, E. M. (1982), Banded corals: Changes in oceanic carbon-14 during the Little Ice Age, Science, 218,13-19, doi:10.1126/ science.218.4567.13

Druffel, E. R. M. (1997), Pulses of rapid ventilation in the North Atlantic surface ocean during the past century, Science, 275, 1454-1457 doi:10.1126/science.275.5305.1454.

Dunbar, R. B., G. M. Wellington, M. W. Colgan, and W. Peter (1994), Eastern Pacific sea surface temperature since $1600 \mathrm{AD}$ : The $\delta^{18} \mathrm{O}$ record of climate variability in Galapagos corals, Paleoceanography, 9, 291-315, doi:10.1029/ 93PA03501.

Esper, J., E. R. Cook, and F. H. Schweingruber (2002), Low-frequency signals in long treering chronologies for reconstructing past temperature variability, Science, 295, 2250-2253, doi:10.1126/science.1066208.

Ferrier-Pages, C., F. Boisson, D. Allemand, and E. Tambutte (2002), Kinetics of strontium uptake in the scleractinian coral Stylophora pistillata, Mar. Ecol. Prog. Ser, 245, $93-$ 100, doi:10.3354/meps245093.

Gagan, M. K., L. K. Ayliffe, D. Hopley, J. A. Cali, G. E. Mortimer, J. Chappell, M. T. McCulloch, and M. J. Head (1998), Temperature and surface-ocean water balance of the mid-Holocene tropical western Pacific, Science, 279, 1014-1018, doi:10.1126, science. 279.5353 .1014

Glynn, P. W., E. M. Druffel, and R. B. Dunbar (1983), A dead Central American reef tract: Possible link with the Little Ice Age, J. Mar Res., 41, 605-637.

Goodkin, N. F. (2007), Geochemistry of slowgrowing corals: Reconstructing sea surface temperature, salinity and the North Atlantic Oscillation, Ph. D. thesis, Mass. Inst. of Technol. and Woods Hole Oceanogr. Inst. Joint Program, Cambridge, Mass.

Goodkin, N. F., K. Hughen, A. C. Cohen, and S. R. Smith (2005), Record of Little Ice Age sea surface temperatures at Bermuda using a growth-dependent calibration of coral $\mathrm{Sr} / \mathrm{Ca}$, Paleoceanography, 20, PA4016, doi:10.1029/ 2005PA001140.

Goodkin, N. F., K. Hughen, and A. C. Cohen (2007), A multicoral calibration method to approximate a universal equation relating $\mathrm{Sr} / \mathrm{Ca}$ and growth rate to sea surface temperature, Paleoceanography, 22, PA1214, doi:10.1029/2006PA001312.

Grossman, E. L., and T. L. Ku (1986), Oxygen and carbon isotope fractionation in biogenic arago- 
nite: Temperature effects, Chem. Geol., 59, 5974, doi:10.1016/0009-2541(86)90044-6.

Hammer, C. U., H. B. Clausen, and W. Dansgaard (1980), Greenland ice sheet evidence of postglacial volcanism and its climatic impact, Nature, 288, 230-235, doi:10.1038/288230a0.

Hansen, J., M. Sato, R. Ruedy, K. Lo, D. W. Lea, and M. Medina-Elizade (2006), Global temperature change, Proc. Natl. Acad. Sci. U. S. A., 103, 14,288-14,293, doi:10.1073/ pnas.0606291103.

Iijima, H., H. Kayanne, M. Morimoto, and O. Abe (2005), Interannual sea surface salinity changes in the western Pacific from 1954 to 2000 based on coral isotope analysis, Geophys. Res. Lett., 32, L04608, doi:10.1029/ 2004GL022026.

Intergovernmental Panel on Climate Change (2007), Climate Change 2007: The Physical Science Basis: Contribution of Working Group I to the Fourth Assessment Report of the Intergovernmental Panel on Climate Change, Cambridge Univ. Press, New York. (Available at http://www.ipcc.ch/)

Ip, Y. K., and P. Krishnaveni (1991), Incorporation of strontium $\left({ }^{90} \mathrm{Sr}^{2+}\right)$ into the skeleton of the hermatypic coral Galaxea fascicularis, J. Exp. Zool., 258, 273-276, doi:10.1002/ jez.1402580219.

Jacoby, G., and R. D. D’Arigo (1989), Reconstructed Northern Hemisphere annual temperature since 1671 based on high-latitude tree-ring data from North America, Clim. Change, 14, 39-59, doi:10.1007/BF00140174.

Jones, P. D., T. J. Osborn, and K. R. Briffa (1997), Estimating sampling errors in largescale temperature averages, J. Clim., 10, 2548-2568, doi:10.1175/1520-0442(1997) 010<2548:ESEILS > 2.0.CO;2.

Jones, P. D., K. R. Briffa, T. P. Barnett, and S. F. B. Tett (1998), High-resolution palaeoclimatic records for the last millennium: Interpretation, integration and comparison with general circulation model control-run temperatures, Holocene, 8, 455-471, doi:10.1191/ 095968398667194956.

Jones, P. D., T. J. Osborn, K. R. Briffa, C. K. Folland, E. B. Horton, L. V. Alexander, D. E. Parker, and N. A. Rayner (2001), Adjusting for sampling density in grid box land and ocean surface temperature time series, J. Geophys. Res., 106, 3371-3380.

Keigwin, L. D. (1996), The Little Ice Age and Medieval warm period in the Sargasso Sea, Science, 274, 1504-1508, doi:10.1126/ science.274.5292.1504.

Kuhnert, H., T. Crüger, and J. Pätzold (2005), NAO signature in a Bermuda coral $\mathrm{Sr} / \mathrm{Ca}$ record, Geochem. Geophys. Geosyst., 6, Q04004, doi:10.1029/2004GC000786.

Lean, J., J. Beer, and R. Bradley (1995), Reconstruction of solar irradiance since 1610: Implications for climate change, Geophys. Res. Lett., 22, 3195-3198, doi:10.1029/ 95GL03093.
Lund, D. C., and W. B. Curry (2006), Florida Current surface temperature and salinity variability during the last millennium, Paleoceanography, 21, PA2009, doi:10.1029/ 2005 PA001218

Lund, D. C., J. Lynch-Stieglitz, and W. B. Curry (2006), Gulf Stream density structure and transport during the past millennium, Nature, 444, 601-604, doi:10.1038/nature05277.

Luterbacher, J., C. Schmutz, D. Gyalistras, E. Xoplaki, and H. Wanner (1999), Reconstruction of monthly NAO and EU indices back to AD 1675, Geophys. Res. Lett., 26 2745-2748, doi:10.1029/1999GL900576.

McConnaughey, T. (1989a), ${ }^{13} \mathrm{C}$ and ${ }^{18} \mathrm{O}$ isotopic disequilibrium in biological carbonates: I. Patterns, Geochim. Cosmochim. Acta, 53, 151162, doi:10.1016/0016-7037(89)90282-2.

McConnaughey, T. (1989b), ${ }^{13} \mathrm{C}$ and ${ }^{18} \mathrm{O}$ isotopic disequilibrium in biological carbonates: II In vitro simulation of kinetic isotope effects, Geochim. Cosmochim. Acta, 53, 163-171, doi:10.1016/0016-7037(89)90283-4.

Ohkouchi, N., T. I. Eglinton, L. D. Keigwin, and J. M. Hayes (2002), Spatial and temporal offsets between proxy records in a sediment drift, Science, 298, 1224-1227, doi:10.1126/ science. 1075287

Overpeck, J., et al. (1997), Arctic environmenta change of the last four centuries, Science, 278 $1251-1256$, doi: $10.1126 /$ science. 278 5341.1251

Quinn, T. M., and D. E. Sampson (2002), A multiproxy approach to reconstructing sea surface conditions using coral skeleton geochemistry, Paleoceanography, 17(4), 1062 , doi:10.1029/2000PA000528.

Rayner, N. A., D. E. Parker, E. B. Horton, C. K. Folland, L. V. Alexander, D. P. Rowell, W. C. Kent, and A. Kaplan (2003), Global analyses of sea surface temperature, sea ice, and nigh marine air temperature since the late nineteenth century, J. Geophys. Res., 108(D14), 4407, doi:10.1029/2002JD002670.

Reverdin, G., D. Cayan, and Y. Kushnir (1997), Decadal variability of hydrography in the uppe northern North Atlantic 1948-1990, J. Geo phys. Res., 102, 8505-8531, doi:10.1029/ 96JC03943.

Rosenheim, B., P. K. Swart, S. Thorrold, A. Eisenhauer, and P. Willenz (2005), Salinity change in the subtropical Atlantic: Secular increase and teleconnections to the North Atlantic Oscillation, Geophys. Res. Lett., 32, L02603, doi:10.1029/2004GL021499.

Sachs, J. P., and S. Lehman (1999), Subtropical North Atlantic temperatures 60,000 to 30,000 years ago, Science, 286, 756-759, doi:10.1126/science.286.5440.756.

Schrag, D. P. (1999), Rapid analysis of highprecision $\mathrm{Sr} / \mathrm{Ca}$ ratios in corals and other marine carbonates, Paleoceanography, 14, 97-102, doi:10.1029/1998PA900025.

Smith, S. V., R. W. Buddemeier, R. C. Redalje, and J. E. Houck (1979), Strontium-calcium thermometry in coral skeletons, Science, 204, 404-407, doi:10.1126/science.204.4391.404.

Swart, P. K., H. Elderfield, and M. J. Greaves (2002), A high-resolution calibration of $\mathrm{Sr} / \mathrm{Ca}$ thermometry using the Caribbean coral Montastraea annularis, Geochem. Geophys. Geosyst., 3(11), 8402, doi:10.1029/ 2002 GC000306.

Sweeney, E. N. M., D. J. McGillicuddy, and K. O. Buesseler (2003), Biogeochemical impacts due to mesoscale eddy activity in the Sargasso Sea as measured at the Bermuda Atlantic Time-series Study (BATS), Deep Sea Res., Part II, 50, 3017-3039, doi:10.1016/ j.dsr2.2003.07.008

Talley, L. D. (1996), North Atlantic circulation and variability, reviewed for the CNLS conference, Physica D, 98, 625-646, doi:10.1016 0167-2789(96)00123-6.

Visbeck, M., E. Chassignet, R. Curry, T. Delworth, R. Dickson, and G. Krahmann, (2003), The ocean's response to North Atlantic Oscillation variability), in The North Atlantic Oscillation: Climate Significance and Environmental Impact, Geophys. Monogr. Ser., vol. 134, edited by J. W. Hurrell et al., pp. 113-145, AGU, Washington, D. C

Watanabe, T., A. Winter, and T. Oba (2001), Seasonal changes in sea surface temperature and salinity during the Little Ice Age in the Caribbean Sea deduced from $\mathrm{Mg} / \mathrm{Ca}$ and ${ }^{18} \mathrm{O} /{ }^{16} \mathrm{O}$ ratios in corals, Mar. Geol., 173 , 21-35, doi:10.1016/S0025-3227(00)00166-3.

Wigley, T. M. L., and P. M. Kelly (1990), Holocene climatic change, ${ }^{14} \mathrm{C}$ wiggles and variations in solar irradiance, Philos. Trans. R. Soc London, Ser. A, 330, 547-560.

Wigley, T. M. L., R. A. Ammann, B. D. Santer, and S. C. B. Raper (2005), Effect of climate sensitivity on the response to volcanic forcing, J. Geophys. Res., 110, D09107, doi:10.1029/ 2004JD005557.

Winter, A., H. Ishioroshi, T. Watanabe, T. Oba, and J. Christy (2000), Caribbean sea surface temperatures: Two-to-three degrees cooler than the present during the Little Ice Age, Geophys. Res. Lett., 27, 3365-3368, doi:10.1029/ 2000GL011426.

W. B. Curry and D. R. Ostermann, Department of Marine Geology and Geophysics, Woods Hole Oceanographic Institute, M. S. 23, Woods Hole, MA 02543, USA.

S. C. Doney and K. A. Hughen, Department of Marine Chemistry and Geochemistry, Woods Hole Oceanographic Institution, M.S. 25, Woods Hole, MA 02543, USA.

N. F. Goodkin, Bermuda Institute of Ocean Sciences, 17 Ferry Reach, St. Georges, GE01, Bermuda. (nathalie.goodkin@bios.edu) 